\title{
Postharvest Quality and Acceptance of LB8-9 Mandarin as a New Fresh Fruit Cultivar
}

\author{
Huating Dou ${ }^{1}$ and Fred G. Gmitter ${ }^{2}$
}

AdDitional InDEX wORDs. 'Minneola', 'Sunburst', peel color, chilling injury, postharvest pitting, decay, sucrose

Summary. A new mandarin cultivar currently designated as selection LB8-9

['Clementine' mandarin (Citrus reticulata) $\times$ 'Minneola' tangelo, Duncan grapefruit (Citrus paradisi) $\times$ Dancy tangerine (C. reticulata)], soon to be released by the University of Florida, Citrus Research and Education Center, Lake Alfred, has been evaluated for postharvest fruit quality and consumer acceptance. Comparisons were made with 'Sunburst' and 'Minneola' mandarins, which overlap the early and late LB8-9 maturity season, respectively. LB8-9 and 'Sunburst' fruit stored 2 weeks at $70{ }^{\circ} \mathrm{F}$ developed similar decay percentages (35\% to $\left.37 \%\right)$, while 'Minneola' showed only $16 \%$ decay. Postharvest pitting incidence was zero in LB8-9 and 'Minneola' and 3\% in 'Sunburst' stored at $70{ }^{\circ} \mathrm{F}$ and $92 \%$ to $96 \%$ relative humidity ( $\mathrm{RH})$. At the same storage conditions, LB8-9 and 'Sunburst' developed better fruit peel color (hue $=60$ ) in comparison with the 'Minneola' (hue $=65$ ) mandarin. No differences were found in fruit external peel color (hue angle), chilling injury, or decay among three cultivars stored at $40{ }^{\circ} \mathrm{F}$ after 6 weeks. However, juice color was the best in 'Sunburst' as indicated by the highest color numbers (44), followed by LB8-9 (40) and 'Minneola' (38). Wax-formulation studies indicated that carnauba wax was the best formulation for coating LB8-9 because of low decay incidence, weight loss, and good color. No difference was found in fruit taste panels at day 6 after packing, while a better score of acceptance in the fruit taste panel was recorded for LB8-9 than 'Minneola' after $50 \mathrm{~d}$ of storage at $40{ }^{\circ} \mathrm{F}$ and $92 \%$ to $96 \% \mathrm{RH}$. LB8 -9 fruit had a higher soluble solids concentration [SSC (14.0)] and acid (1.12) than 'Minneola' or 'Sunburst' mandarins, both having a SSC and acid lower than 11.5 and 0.86 , respectively. Sucrose concentration was noticeably higher in the new cultivar $(7.14 \mathrm{~g} / 100 \mathrm{~mL})$ than in 'Minneola' $(5.27 \mathrm{~g} / 100 \mathrm{~mL})$ or 'Sunburst' $(6.10 \mathrm{~g} / 100 \mathrm{~mL})$. Vitamin C concentration was $42.43 \mathrm{mg} / 100 \mathrm{~mL}$ for the new cultivar, which was considerably higher than 'Minneola' $(23.27 \mathrm{mg} / 100 \mathrm{~mL})$ or 'Sunburst' $(26.25 \mathrm{mg} / 100 \mathrm{~mL})$. Overall, LB8-9 has good potential as a new fresh fruit for the consumer, and no serious problems were noted with typical postharvest handling.

$\mathrm{T}$ raditionally, citrus in Florida is well-known as a processing industry in which $92 \%$ to $95 \%$ of oranges produced are juiced (Sparks and Ismail, 2000). However, in recent years, a strong demand has developed for fresh fruit. In particular, this increased demand has occurred primarily in specialty fruit, mainly mandarins. The Fresh Orange and Specialty Advisory Council, under the Florida Citrus Commission, is planning to release three new cultivars each year for fresh fruit production beginning in 2006. From the viewpoints of propagation and production, these cultivars should be selected for characteristics favored by American consumers, such as seedlessness, ease of peeling, good color, and shelf-life stability. In addition, fruit should have good organoleptic qualities and mature early or late to extend the season as long as possible.
The Florida Department of Citrus (FDOC) conducted a survey recently and summarized the consumer preferences for new cultivars (A.B. Morrissey, personal communication). 'Satsuma' and 'Clementine' mandarins are two cultivars grown in California, Spain, Japan, and Morocco that possess characteristics described above (Saunt, 2000). In particular, new 'Clementine' groves have been planted in California recently, and production has been increased rapidly for the domestic market (California Citrus Research Board, Visalia, Calif.). However, these two cultivars are not suitable for growth under Florida climatic conditions, producing fruit of poor color and internal quality (Davies and Albrigo, 1994).

The LB8-9 mandarin is a new cultivar developed by the cultivar development group at University of Florida, Citrus Research and Education Center, Lake Alfred (CREC). This new cultivar has been tested commercially for several years. LB8-9 matures between late November and early January under Florida climatic conditions. In addition, LB8-9 is similar to 'Sunburst' and 'Minneola' from a genetic standpoint and matures before 'Minneola' and after 'Sunburst' mandarin (Tucker et al., 2006). 'Sunburst' is characterized by good fruit color but not outstanding taste. 'Minneola' mandarin has poor fruit color and is not fully mature until January, although it is frequently harvested earlier for the holiday season. The typical maturity period for 'Sunburst' is between November and December, and that for 'Minneola' is between December and January (Tucker et al., 2006). In addition, 'Minneola' has a low ontree storage capability and a short marketing period. The LB8-9 mandarin matures in December, which is suitable for gift-fruit packing before

This research was supported by the Florida Citrus Production Advisory Council (0110-31 I) and the Florida Agricultural Experiment Station.

Use of trade names does not imply endorsement of the products named or criticism of similar ones not named.

${ }^{1}$ Florida Department of Citrus, 700 Experiment Station Road, Citrus Research and Education Center, Lake Alfred, FL 33850.

${ }^{2}$ University of Florida, Institute of Food and Agricultural Sciences, Horticultural Sciences Department, Citrus Research and Education Center, 700 Experiment Station Road, Lake Alfred, FL 33850.

${ }^{3}$ Corresponding author. E-mail: douh@basf.com

\begin{tabular}{llll}
\hline $\begin{array}{l}\text { Units } \\
\begin{array}{l}\text { To convert U.S. to SI, } \\
\text { multiply by }\end{array}\end{array}$ & U.S. unit & SI unit & $\begin{array}{l}\text { To convert SI to U.S., } \\
\text { multiply by }\end{array}$ \\
\hline 29,574 & $\mathrm{fl} \mathrm{oz}$ & $\mu \mathrm{L}$ & $3.3814 \times 10^{-5}$ \\
29.5735 & $\mathrm{fl} \mathrm{oz}$ & $\mathrm{mL}$ & 0.0338 \\
2.54 & inch $(\mathrm{es})$ & $\mathrm{cm}$ & 0.3937 \\
1 & $\mathrm{micron}$ & $\mu \mathrm{m}$ & 1 \\
28.3495 & $\mathrm{Oz}$ & $\mathrm{g}$ & 0.0353 \\
0.0001 & $\mathrm{ppm}$ & $\mathrm{g} / 100 \mathrm{~mL}$ & 10,000 \\
0.1 & $\mathrm{ppm}$ & $\mathrm{mg} / 100 \mathrm{~mL}$ & 10 \\
$\left({ }^{\circ} \mathrm{F}-32\right) \div 1.8$ & ${ }^{\circ} \mathrm{F}$ & ${ }^{\circ} \mathrm{C}$ & $\left(1.8 \times{ }^{\circ} \mathrm{C}\right)+32$
\end{tabular}


Christmas. Earlier maturity and similarity of LB8-9 to 'Minneola' may result in an extended season for 'Minneola'-type fruit. It could potentially replace 'Minneola'. From a production viewpoint, LB8-9 is an excellent cultivar with a rich taste/ flavor and is well suited for the fresh fruit market during the holiday season.

The objectives of this study are to systematically investigate the optimal postharvest handling of LB8-9, to evaluate the internal nutritional characteristics and flavor, and to provide information for packers and shippers.

\section{Materials and methods}

Study 1. Coating evaluation FOR LB8-9 IN THE 2002-2003 SEASON. One bin $(\approx 1800$ fruit, between 6.8 and $9.0 \mathrm{~cm}$ in diameter) of LB8-9 was harvested from a new cultivar development grove at CREC on 30 Nov. 2002. Trees were 11-14 years old and grown on Swingle citrumelo (C. paradisi $\times$ Poncirus trifoliata) rootstock. Fruit were handsnapped, equally from four directions of 16 trees at an outside canopy. Fruit were stored at $70{ }^{\circ} \mathrm{F}$ and $92 \%$ to $96 \%$ RH overnight. On the second day, fruit were washed with commercial fruit cleaner (Sooty Mold Clean 278; Decco Cerexagri, Inc., Monrovia, Calif.), dried at $45{ }^{\circ} \mathrm{C}$, and waxed with carnauba (State Fresh 921; FMC Corp., Lakeland, Fla.), polyethylene (State Fresh 4201; FMC Corp.), and shellac (State Fresh 590; FMC Corp.) waxes, respectively. A nonwaxed treatment served as a control. There were a total of four treatments. Each treatment consisted of three replications with 45 fruit per replication. Fruit used were midsize, and weights per fruit varied between 190 and $210 \mathrm{~g}$. Fruit were examined for chilling injury (CI) and decay after 3 months of storage at $40^{\circ} \mathrm{F}$ with $92 \% \pm 3 \%$ RH. Fruit weight loss per treatment was investigated between day 1 and day 14, and peel color was measured at day 40. After fruit examination at day 90 , fruit internal vitamin C, sucrose, SSC, and titratable acidity (TA) were determined as described in the additional studies below.

STUdy 2. Postharvest QUALITY OF LB8-9 IN COMPARISON WITH 'Sunburst' AND 'MinNEOLA' DURING THE 2003-2004 SEASON. LB8-9, 'Sunburst', and 'Minneola' grown on Swingle citrumelo root- stock were harvested from a CREC grove designed for the breeding program located in Lake Alfred, Fla., on 3 Dec. 2003. Five hundred fruit in similar size $(6.8-9.0 \mathrm{~cm}$ in diameter) were hand-snapped equally from four directions of five trees for each cultivar. Fruit were washed as described in Study 1. After being washed, fruit were waxed, respectively, with carnauba (State Fresh 921), polyethylene (State Fresh 4201), and shellac wax (State Fresh 590) and stored at $70{ }^{\circ} \mathrm{F}$ and $92 \%$ to $96 \% \mathrm{RH}$. The waxes used in this study contained $18 \%$ to $20 \%$ SSC. This is a factorial design with three waxes and three cultivars, respectively. Four replicates for each treatment were carried out, with 30 fruit in each replication. For fruit internal analysis and taste panel use, 100 additional fruit of each cultivar were waxed with only carnauba wax (State Fresh 921) and stored $90 \mathrm{~d}$ at $40{ }^{\circ} \mathrm{F}$ and $92 \%$ to $96 \% \mathrm{RH}$.

Study 3. Coating evaluation FOR LB8-9 IN THE 2004-2005 SEASON. The experiment described in Study 1 was repeated during the 2004-2005 season with fruit harvested on 13 Dec. 2004. Postharvest handling and storage conditions were the same as described in Study 1. This was a block design with three major commercial waxes. Fruit were examined for decay and CI after 3 months of storage at $40{ }^{\circ} \mathrm{F}$ with $92 \% \pm 3 \% \mathrm{RH}$. Fruit weight loss and color were not measured. After $90 \mathrm{~d}$ in storage, fruit internal vitamin C, SSC, and TA were determined.

Study 4. Postharvest Quality OF LB 8-9 IN COMPARISON WITH 'SUnburst' AND 'MinNeOLA' DURING THE 2004-2005 SEASON. The quality of LB8-9 was again compared with 'Sunburst' and 'Minneola' during the 2004-2005 season. The fruit were snapped from the same trees in grove as described in Study 2 on 13 Dec. 2004. Fruit were handled the same as in Study 2 and waxed with carnauba wax (State Fresh 921). After that, fruit were stored at $70{ }^{\circ} \mathrm{F}$ and $92 \%$ to $96 \%$ RH. Four replications were carried out for each cultivar with 60 fruit in each replication. Fruit decay and postharvest pitting (PP) were examined at day 14 . Another set of 100 fruit of each cultivar was stored $90 \mathrm{~d}$ at $40{ }^{\circ} \mathrm{F}$ and $92 \%$ to $96 \% \mathrm{RH}$, for fruit internal analysis. Taste panel was conducted at day 50. Sugar was not analyzed in this study.

Disorder evaluation. Postharvest pitting was defined as a new peel disorder incited by wax application and high-temperature $\left(>15{ }^{\circ} \mathrm{C}\right)$ storage less than 2 weeks while CI is a classical disorder incited by lowtemperature $\left(<4^{\circ} \mathrm{C}\right)$ storage for at least 4 weeks (Dou, 2004; Petracek et al., 1998). PP of fruit was rated visually ( $0=$ no pits, $1=1-3$ pits, $2=4-10$ pits, $3=11-30$ pits, $4=31-100$ pits, and $5=$ more than 100 pits) as described previously (Petracek et al., 1998). CI was rated by subjectively assigning each fruit a numerical rating of 0 no damage), 1 (slight, $<5 \%$ of fruit surface damaged), 2 (moderate, $5 \%$ to $49 \%$ of fruit surface damaged), or 3 (severe, $50 \%$ to $100 \%$ of fruit surface damaged) (Dou, 2004). Percentages of CI and PP for each replication within a treatment were calculated and statistically analyzed.

MeAsurement of Weight Loss. Weight was measured on day 1 and day 14. Weight loss was expressed as the percentage change in mass between measuring periods for 10 fruit per each treatment at respective studies stored at $40{ }^{\circ} \mathrm{F}$ and $92 \%$ to 96\% RH.

MEASUREMENT OF FRUIT EXTERNAL COLOR. Fruit color of four surface regions along the midsection spaced $90^{\circ}$ apart was measured in 10 fruit using a colorimeter (CR-A45; Minolta USA, Ramsey, N.J.). Tristimulus values $(X, x$, and $y)$ were converted to hue angle $\left(0^{\circ}=\right.$ red-purple, $90^{\circ}=$ yellow, $180^{\circ}=$ bluish-green, $270^{\circ}=$ blue) according to McGuire $(1992)$. Low hue value $\left(<75^{\circ}\right)$ indicates a yellowish-orange color, while high hue $\left(>75^{\circ}\right)$ is an indication of greenish-yellow color.

JUICE SAMPLE PREPARATION. Twenty fruit of each treatment from respective replicates were collected and hand-juiced (Handy Juicer; Black and Decker, Shelton, Conn.). Extracted juice was filtered through two layers of cheesecloth; juice color, SSC, and TA were measured the same day. The juice was then stored overnight at $40{ }^{\circ} \mathrm{F}$ before being evaluated for vitamin $\mathrm{C}$, fructose, glucose, and sucrose on the following day.

JUICE COLOR MEASUREMENT. Fruit juice color was measured in a spectrophotometer (Macbeth ColorEye 3100; Kollmorgh Instruments 
Corp., Baltimore, Md.) according to Lee (2000).

Analysis of Juice SSC and TA. Juice SSC made from fresh fruit was measured using a table-model refractometer with temperature and acid corrections (Mark II; Leica, Buffalo, N.Y.). Percentage of TA was determined by titration with standard alkali using phenolphthalein indicator at pH 8.20.

ANALYsis of FRUIT vitamin C. Vitamin $\mathrm{C}$ was analyzed with a highpressure liquid chromatography (HPLC) system (model 5.5; Waters Associates, Milford, Mass.) coupled with a YMC ODS-AO guard column (Phenomenex, Torrance, Calif.) using a model spectra 200-ultraviolet/visible detector (SpectraPhysics, San Jose, Calif.). The column was run at ambient temperature $\left(28-30{ }^{\circ} \mathrm{C}\right)$. A mobile phase of $2 \%$ potassium phosphate monobasic $\left(\mathrm{KH}_{2} \mathrm{PO}_{4}\right)$ at $\mathrm{pH} 2.4 \pm 0.01$ was used for vitamin C analysis. Two milliliters of juice were mixed with $2 \mathrm{~mL}$ of $2.4 \%(\mathrm{w} / \mathrm{v})$ metaphosphoric acid and centrifuged at $6900 g_{\mathrm{n}}$ for $5 \mathrm{~min}$ at $5{ }^{\circ} \mathrm{C}$. An aliquot of the centrifuged sample $(0.5 \mathrm{~mL})$ was then transferred to a $10-\mathrm{mL}$ volumetric flask and brought to volume with $2.5 \%(\mathrm{w} / \mathrm{v})$ metaphosphoric acid. The sample was then filtered through a $0.45-\mu \mathrm{m}$ nylon syringe filter (Fisher Scientific, Pittsburgh) before injection. Vitamin $\mathrm{C}$ was analyzed by injecting $10 \mu \mathrm{L}$ of sample with an automatic sampler onto the column as described above. Flow rate was $0.4 \mathrm{~mL} \cdot \mathrm{min}^{-1}$. A detailed description of vitamin $\mathrm{C}$ analysis was carried out according to the HPLC procedure of Lee and Coates (1987).

Analysis of Juice Sugar CONCENTRATION. Fruit juice sugar concentration was analyzed by the same HPLC system as was used in the vitamin $\mathrm{C}$ analysis. A Mac-Mod Analytical Zorbax $\mathrm{NH}_{2}$ column (Hewlett Packard, Palo Alto, Calif.) coupled with a refractive index detector (Hewlett Packard) were set for sugar analysis at $30{ }^{\circ} \mathrm{C}$. HPLC-grade acetonitrile from Fisher Scientific was used for the mobile phase. About $6 \mathrm{~mL}$ of juice was centrifuged at 6900 $g_{\mathrm{n}}$ for $5 \mathrm{~min}$. Three milliliters of juice were passed through a $\mathrm{C}_{18}$ Sep-Pak (Waters Associates) cartridge that had been conditioned by rinses with $3 \mathrm{~mL}$ of methanol followed by two individ- ual rinses of $3 \mathrm{~mL}$ deionized water. The first $1.5 \mathrm{~mL}$ of juice passed through the cartridge was discarded, and the remainder of the juice was collected. Ten-microliter samples were injected into the HPLC system automatically. Flow rate was $1.0 \mathrm{~mL} \cdot \mathrm{min}^{-1}$.

Taste panel. A taste panel was conducted at the CREC taste panel laboratory on day 6 and day 50 with 20 panelists for Study 2, and only at day 50 for Study 4 . Forty fruit stored at $40{ }^{\circ} \mathrm{F}$ and $92 \%$ to $96 \% \mathrm{RH}$ were juiced each time using a Handy Juicer as described in "Juice Sample Preparation." Panelists were asked to score the juice on a scale of 1 to 9 on a ninepoint acceptance scale, a well-known a hedonic sensory evaluation (Meilgaard et al., 1999). Panelists were the research staff at CREC and recognized as trained panelists. Because fruit slices may have a greater variation than juice due to fruit orientation on-tree (i.e., inside and outside of the canopy) as well as to fruit size, freshly made juice is routinely used in taste panels as it is more representative of the fruit than fruit slices.

Statistical analysis. Study 2 was a factorial design, while Studies 1,3 , and 4 were organized in a completely randomized block design. Data were analyzed accordingly by factorial analysis and analysis of variance using statistical software (PlotIT; Scientific Programming Enterprises, Haslett, Mich.). Means were separated by Duncan's new multiple range test at $P \leq 0.05$ for Studies 1, 3, and 4 . For Study 2, the least significant difference (LSD) method was used after the factorial analysis at $P \leq 0.05$.

\section{Results}

Coating evaluation for LB8-9. In the 2002-2003 season, wax application on LB8-9 significantly reduced $\mathrm{CI}$ and weight loss when fruit were stored at $40^{\circ} \mathrm{F}$ for $90 \mathrm{~d}$ (Table $\mathrm{l}$ ). No difference was found among the three wax types in protecting fruit from chilling development. However, decay was lower in fruit that were not coated and in those coated with carnauba wax in comparison with shellac- or polyethylene-waxed fruit. In the 2004-2005 season, decay was higher in shellac-waxed fruit than in polyethylene- or carnauba-waxed fruit. No difference was found in fruit CI incidence stored at $40{ }^{\circ} \mathrm{F}$ for $90 \mathrm{~d}$. Fruit peel color (hue angle) and weight loss were not measured during the 2004-2005 season. A better fruit color was developed in carnaubawaxed fruit than in polyethylenewaxed fruit, as indicated by a hue value lower in the former fruit than in the latter one during the 20022003 season.

Fruit internal SSC did not change from day 0 to day 90 in polyethylene-waxed fruit, while SSC was the highest in carnauba-waxed fruit for all three wax treatments in the 2002-2003 study. Surprisingly, SSC increased two units in nonwaxed fruit during the storage period $(90 \mathrm{~d})$. During the 2004-2005 study, SSC was increased one unit from day 0 to day 90 in all waxed fruit. TA decreased in all coating treatments after $90 \mathrm{~d}$ storage in comparison with day 0 and noncoated fruit in both study years. Vitamin C also showed a decrease during storage and in coated compared with noncoated fruit. The magnitude of vitamin $\mathrm{C}$ reduction was larger in the 2004-2005 season than that in the 2002-2003 season. Total sugar concentration was increased except for fruit coated with shellac wax during the 2002-2003 season (Table 2).

PosthaRvest QUality OF LB8-9 IN COMPARISON WITH 'SUNBURST' AND 'Minneola'. Fruit PP incidence, decay, and surface color were significantly different among the three cultivars, while wax type only significantly influenced fruit decay development (Table 3). Among cultivars, PP was higher in 'Sunburst' but lower in LB8-9 and 'Minneola'. Decay was lowest in 'Minneola', but 'Sunburst' and LB8-9 had better fruit surface color than 'Minneola', as indicated by a low hue angle value. Among the three wax types, shellac-coated fruit resulted in the highest incidence of fruit decay (Table 3 ). In the 20042005 study, no PP was developed in three cultivars; however, decay values were $4.4 \%, 5.2 \%$, and $8.8 \%$ for the respective 'Minneola', LB8-9, and 'Sunburst' mandarins. The decay incidence is significantly higher in 'Sunburst' than in LB8-9 or 'Minneola' mandarins.

LB8-9 had a higher SSC, TA, and vitamin $\mathrm{C}$ content than 'Sunburst' or 'Minneola' in the 20032004 study. In particular, the vitamin C concentration in LB8-9 was almost twice that in 'Minneola' or 'Sunburst' 
Table 1. Effect of wax type on chilling injury (CI), decay incidence, weight loss, and peel color development of LB8-9 mandarin. ${ }^{\mathrm{z}}$

\begin{tabular}{|c|c|c|c|c|}
\hline Waxes & $\begin{array}{l}\text { CI (\%) } \\
\text { day } 90 \\
\end{array}$ & $\begin{array}{c}\text { Decay }(\%) \\
\text { day } 90\end{array}$ & $\begin{array}{l}\text { Wt loss } \\
(\% / d)\end{array}$ & $\begin{array}{c}\text { Peel color }\left(b^{\circ}\right) \\
\text { day } 40\end{array}$ \\
\hline \multicolumn{5}{|c|}{$2002-2003$} \\
\hline No wax & $32.1 \mathrm{~b}^{\mathrm{y}}$ & $0.7 \mathrm{a}$ & $0.160 \mathrm{~b}$ & $63.2 \mathrm{a}$ \\
\hline Polyethylene & $7.7 \mathrm{a}$ & $4.9 \mathrm{~b}$ & $0.081 \mathrm{a}$ & $66.0 \mathrm{~b}$ \\
\hline Carnauba & $8.4 \mathrm{a}$ & $1.7 \mathrm{a}$ & $0.071 \mathrm{a}$ & $63.0 \mathrm{a}$ \\
\hline Shellac & $9.8 \mathrm{a}$ & $\begin{array}{c}4.0 \mathrm{~b} \\
\mathbf{2 0 0 4 - 2 0 0 5}\end{array}$ & $0.085 \mathrm{a}$ & $63.7 \mathrm{ab}$ \\
\hline Polyethylene & $0 \mathrm{a}$ & $5.0 \mathrm{a}$ & $\mathrm{ND}^{\mathrm{x}}$ & ND \\
\hline Carnauba & $0 \mathrm{a}$ & $5.2 \mathrm{a}$ & ND & ND \\
\hline Shellac & $0 \mathrm{a}$ & $7.7 \mathrm{~b}$ & ND & ND \\
\hline
\end{tabular}

${ }^{2}$ The fruit examination and color measurement data were based on the marketing period of mandarins. Weight loss was determined between day 1 and day 14 due to possible decay development of individual fruit after day 14 . LB8-9 mandarin was stored at $40{ }^{\circ} \mathrm{F}\left(4.4^{\circ} \mathrm{C}\right)$ and $92 \%$ to $96 \%$ relative humidity.

yifferent letters in same column mean significantly different according to Duncan's multiple range test at $P \leq 0.05$.

${ }^{\mathrm{x}} \mathrm{ND}=$ no data (fruit weight loss and color were not measured).

(Table 4). During the 2004-2005 season, the differences in SSC, TA, and vitamin $\mathrm{C}$ concentrations were small between LB8-9 and 'Sunburst' mandarins, although LB8-9 clearly showed higher amounts of SSC and vitamin C than did 'Minneola' (Table 4). 'Sunburst' fruit had the best fruit juice color followed by LB8-9 in a 2 -year study. Fruit internal acid and vitamin $\mathrm{C}$ were decreased from day 0 through day 30 and into day 60 , although changes in SSC and juice color number were small during storage. LB8-9 was also characterized by higher fruit internal fructose, glucose, and sucrose than 'Sunburst' or 'Minneola' (Table 5). However, the taste panels did not indicate a significant difference for preference of juice of
LB8-9 above 'Sunburst' or 'Minneola' at day 6; but the taste panels did show an acceptance for 'Sunburst' over the other two cultivars at day 50 in the 2003-2004 study. In the 2004-2005 season, LB8-9 was shown to have equal acceptance as 'Sunburst' and was preferred over 'Minneola' at day 50 (Table 6).

\section{Discussion}

Overall, LB8-9 has more positive attributes than 'Sunburst' or 'Minneola'. For example, decay is lower in LB8-9 than in 'Sunburst'; peel color, juice color, and vitamin $\mathrm{C}$ are higher than in 'Minneola' (Tables 3 and 4). In particular, fructose is $30 \%$ higher in LB8-9 $(3.01 \mathrm{~g} / 100 \mathrm{~mL})$ than in 'Sunburst' $(2.19 \mathrm{~g} / 100 \mathrm{~mL})$ and

Table 2. Influence of wax type on fruit juice SSC, TA, and vitamin C and sucrose concentrations of LB8-9 mandarin. ${ }^{2}$

\begin{tabular}{lccccc}
\hline Wax type & $\begin{array}{c}\text { Time in } \\
\text { storage } \\
(\mathbf{d})\end{array}$ & SSC (\%) & TA (\%) & $\begin{array}{c}\text { Vitamin C } \\
(\mathbf{m g} / \mathbf{1 0 0} \mathbf{~ m L} \\
\text { juice })^{\mathbf{x}}\end{array}$ & $\begin{array}{c}\text { Sucrose } \\
(\mathbf{g} / \mathbf{1 0 0} \mathbf{~ m L} \\
\text { juice })^{\mathbf{x}}\end{array}$ \\
\hline No wax & 0 & $12.4 \mathrm{~b}^{\mathrm{y}}$ & $0.98 \mathrm{~d}$ & $31.8 \mathrm{~b}$ & $6.54 \mathrm{a}$ \\
No wax & 90 & $14.0 \mathrm{~d}$ & $0.84 \mathrm{c}$ & $\mathbf{3 2 . 7} \mathrm{b}$ & $7.82 \mathrm{~d}$ \\
Polyethylene & 90 & $12.4 \mathrm{~b}$ & $0.74 \mathrm{a}$ & $29.8 \mathrm{a}$ & $7.27 \mathrm{c}$ \\
Carnauba & 90 & $12.6 \mathrm{c}$ & $0.77 \mathrm{~b}$ & $30.0 \mathrm{a}$ & $7.11 \mathrm{~b}$ \\
Shellac wax & 90 & $12.1 \mathrm{a}$ & $0.73 \mathrm{a}$ & $29.8 \mathrm{a}$ & $6.63 \mathrm{a}$ \\
& \multicolumn{2}{c}{$\mathbf{2 0 0 4}-2005$} & & \\
No wax & 0 & $11.7 \mathrm{a}$ & $0.93 \mathrm{~b}$ & $30.3 \mathrm{a}$ & ND \\
Polyethylene & 90 & $12.6 \mathrm{~b}$ & $0.85 \mathrm{~b}$ & $19.3 \mathrm{~b}$ & ND \\
Carnauba & 90 & $12.95 \mathrm{~b}$ & $0.85 \mathrm{~b}$ & $18.6 \mathrm{~b}$ & ND \\
Shellac & 90 & $12.8 \mathrm{~b}$ & $0.90 \mathrm{~b}$ & $27.3 \mathrm{a}$ & ND \\
\hline
\end{tabular}

${ }^{2} \mathrm{LB} 8-9$ mandarin was stored for $90 \mathrm{~d}$ at $40{ }^{\circ} \mathrm{F}\left(4.4{ }^{\circ} \mathrm{C}\right)$ and $92 \%$ to $96 \%$ relative humidity.

'Different letters in same column mean significantly different according to Duncan's multiple range test at $P \leq 0.05$.

${ }^{x} 1 \mathrm{mg} / 100 \mathrm{~mL}=10 \mathrm{ppm} ; 1 \mathrm{~g} / 100 \mathrm{~mL}=10,000 \mathrm{ppm}$.

"ND = no data (sucrose was not measured in the 2004-2005 season).
'Minneola' (2.32 g/l00 mL). The storage study indicated a slow decrease in vitamin $\mathrm{C}$ and TA in LB8-9 fruit. This is particularly true for fruit waxed with shellac rather than with carnauba wax. Shellacwaxed fruit results in fruit external quality deterioration, as shown herein (Tables 1 and 3 ). The cause is the lower gas permeability of shellacwaxed fruit than of fruit waxed with carnauba or polyethylene (Dou, 2004; Hagenmaier and Shaw, 1992). A decrease in vitamin $C$ in the packed juice products has been reported in the past (Nagy and Smoot, 1977), but no report was found regarding the fresh fruit vitamin $C$ changes during the postharvest period. Also, this study showed a higher vitamin $\mathrm{C}$ concentration in nonwaxed than in waxed fruit (Table 2). It is speculated that anaerobic respiration in waxed fruit results in a quick reduction of ascorbic acid in citrus fruit. The positive aspects of wax application, resulting in reductions in fruit $\mathrm{CI}$ and protecting fruit from weight loss, have been discussed by Dou and Ismail (2000) and Petracek et al. (1998). Considering such postharvest characteristics as PP, CI, decay, weight loss, and peel color, the current study indicated that carnauba is the best wax for LB8-9.

A trend of increasing SSC and decreasing TA during storage was observed for all three cultivars. Echeverria and Ismail (1990) found an increase in SSC in 'Hamlin' oranges and 'Robinson' tangerines during 9 weeks of storage at $15^{\circ} \mathrm{C}$. The authors had further stated that such an increase in SSC is not due to water loss and consequential increase in solute concentrations because postharvest water loss in citrus is restricted to the peel (Purvis, 1983). The possible reasons causing this SSC increase and TA decrease is due to the conversion of organic acids to sugars through gluconeogenesis (Echeverria and Valich, 1989). Also, solubilization of cell water constituents by galactosidases and glucosidases may be involved (Echeverria and Ismail, 1990).

LB8-9 behaves similarly to 'Minneola', developing lower pitting and decay than 'Sunburst' among the three cultivars. The lower rate of decay exhibited by 'Minneola' is likely related to the relative immaturity of 
Table 3. Factorial analysis of wax and cultivar in postharvest pitting (PP), decay incidence, and color development of LB8-9, 'Sunburst', and 'Minneola' mandarins during the 2003-2004 season. ${ }^{2}$

\begin{tabular}{|c|c|c|c|}
\hline Variable & PP (\%) & Decay (\%) & Peel color $\left(b^{\circ}\right)$ \\
\hline \multicolumn{4}{|c|}{ Results of factorial analysis } \\
\hline Cultivar & $* * *$ & $* * *$ & $* * *$ \\
\hline Wax type & NS & $* * *$ & NS \\
\hline Interaction & NS & * & NS \\
\hline \multicolumn{4}{|c|}{ Mean separation } \\
\hline LB8-9 mandarin & 0 & 35 & 60.7 \\
\hline Sunburst mandarin & 2.9 & 37 & 60.7 \\
\hline Minneola mandarin & 0 & 16 & 65.1 \\
\hline Carnauba & NS & 20 & NS \\
\hline Polyethylene & NS & 30 & NS \\
\hline Shellac & NS & 38 & NS \\
\hline
\end{tabular}

${ }^{\mathrm{z}}$ Fruit were stored at $70{ }^{\circ} \mathrm{F}\left(21.1^{\circ} \mathrm{C}\right)$ and $92 \%$ to $96 \%$ relative humidity for 2 weeks.

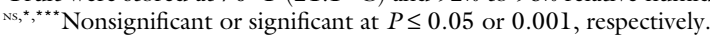

'Minneola' fruit at the time of harvest. This is also the reason that 'Minneola' developed poor fruit peel and juice color in comparison with LB8-9 and 'Sunburst'. The highest sugar concentrations were found in LB8-9 (Table 5), which is particularly important for the fresh fruit since LB8-9 matures earlier than 'Minneola' and at a similar period to 'Sunburst'. This high sugar concentration in LB8-9 demonstrated that it can cover the fresh fruit windows before Christmas by providing good-tasting fruit for the consumer. The taste panel conducted in the 2004-2005 season indicated a similar consumer acceptance of 'Sunburst' and LB8-9, supporting the fact that LB8-9 can be an excellent fresh fruit cultivar. Also, it is obvious that LB8-9 tasted better than 'Minneola', in addition to having better color development. 'Sunburst' and 'Minneola' have been marketed as gift fruit during December and January. However, 'Sunburst' devel-
Table 5. Fruit internal fructose glucose, and sucrose of LB8-9 mandarin in comparison with 'Sunburst' and 'Minneola' mandarins at day 1 after harvest in the 2003-2004 season. $^{z}$

\begin{tabular}{|c|c|c|c|}
\hline \multirow[b]{2}{*}{ Cultivar } & \multicolumn{3}{|c|}{$\begin{array}{c}\text { Internal sugar } \\
\text { concn }(\mathrm{g} / 100 \mathrm{~mL} \text { juice })^{\mathrm{y}}\end{array}$} \\
\hline & Fructose & Glucose & $\mathrm{S}_{1}$ \\
\hline & & & \\
\hline & & & \\
\hline 111110 VIa & 2.020 & $2.18 \mathrm{a}$ & \\
\hline \multicolumn{4}{|c|}{$\begin{array}{l}{ }^{2} \text { Samples were juiced in } 20 \text { fruit at } \\
\left(4.4^{\circ} \mathrm{C}\right) \text { overnight for analysis on } \\
\mathrm{y} 1 \mathrm{~g} / 100 \mathrm{~mL}=10,000 \mathrm{ppm} \text {. } \\
{ }^{x} \text { Different letter in same column } \\
\text { different according to Duncan's mı } \\
P \leq 0.05 \text {. }\end{array}$} \\
\hline
\end{tabular}

ops high decay and 'Minneola' has poor color during this period, as the current studies confirmed.

Results show that LB8-9 mandarin has the positive postharvest characteristics of these two mandarin cultivars in addition to other characteristics, such as seedlessness and easy peeling, as have always been observed. 'Sunburst' and 'Minneola' have more than 8 to 10 seeds per fruit (Tucker et al., 2006), while LB8-9 has only 0 to 4 seeds per fruit (data
Table 4. Fruit juice SSC, TA, vitamin C concentration, and juice color number of LB8-9 mandarin in comparison with 'Sunburst' or 'Minneola' mandarins.

\begin{tabular}{|c|c|c|c|c|c|}
\hline Cultivar & $\begin{array}{c}\text { Time in } \\
\text { storage }(d)\end{array}$ & $\begin{array}{c}\text { SSC } \\
(\%)\end{array}$ & $\begin{array}{l}\text { TA } \\
(\%)\end{array}$ & $\begin{array}{c}\text { Vitamin C } \\
(\mathrm{mg} / 100 \mathrm{~mL})^{\mathrm{w}}\end{array}$ & $\begin{array}{c}\text { Juice } \\
\text { color } \\
\text { no. }\end{array}$ \\
\hline \multicolumn{6}{|c|}{ 2003-2004 season } \\
\hline \multirow[t]{3}{*}{ Sunburst } & 0 & 11.5 & 0.86 & 26.3 & 44.1 \\
\hline & 30 & 11.7 & 0.74 & 23.2 & 44.0 \\
\hline & 60 & 12.0 & 0.71 & 23.0 & 43.7 \\
\hline \multirow[t]{3}{*}{ LB8-9 } & 0 & 14.0 & 1.12 & 42.4 & 40.3 \\
\hline & 30 & 14.4 & 0.9 & 40.5 & 40.3 \\
\hline & 60 & 14.6 & 0.86 & 38.9 & 40.4 \\
\hline \multirow[t]{3}{*}{ Minneola } & 0 & 11.2 & 0.86 & 23.3 & 37.3 \\
\hline & 30 & 11.4 & 0.85 & 21.0 & 38.3 \\
\hline & 60 & 11.5 & 0.76 & 22.6 & 38.5 \\
\hline \multirow[t]{2}{*}{$\operatorname{LSD}^{\mathrm{y}}(P \geq 0.05)$} & \multirow{2}{*}{\multicolumn{4}{|c|}{$\begin{array}{cc}\mathrm{ND}^{\mathrm{x}} & \mathrm{ND} \\
\mathbf{2 0 0 4}-2005 & \text { season }\end{array}$}} & 0.08 \\
\hline & & & & & \\
\hline \multirow[t]{2}{*}{ Sunburst } & 0 & 11.5 & 0.90 & 34.2 & 43.4 \\
\hline & 60 & 12.4 & 0.73 & 15.1 & 44.2 \\
\hline \multirow[t]{2}{*}{ LB8-9 } & 0 & 11.7 & 0.93 & 30.3 & 39.6 \\
\hline & 60 & 12.5 & 0.83 & 27.3 & 40.4 \\
\hline \multirow[t]{2}{*}{ Minneola } & 0 & 9.7 & 0.98 & 19.7 & 38.9 \\
\hline & 60 & 10.2 & 0.94 & 13.0 & 37.6 \\
\hline $\operatorname{LSD}(P \geq 0.05)$ & & $\mathrm{ND}$ & ND & 2.1 & 0.09 \\
\hline
\end{tabular}

${ }^{z} \mathrm{LB} 8-9$ mandarin was stored for 30 or $60 \mathrm{~d}$ at $40{ }^{\circ} \mathrm{F}\left(4.4^{\circ} \mathrm{C}\right)$ and $92 \%$ to $96 \%$ relative humidity.

'Significant difference according to a least significant difference (LSD) method at $P \geq 0.05$.

${ }^{x} \mathrm{ND}=$ no data

${ }^{\mathrm{w}} \mathrm{l} \mathrm{mg} / \mathrm{l} 00 \mathrm{~mL}=10 \mathrm{ppm}$
Table 6. Hedonic score of LB8-9 mandarin in comparison with 'Sunburst' and 'Minneola' mandarins; scores between 1 ("extremely disliked") and 9 ("most liked") were used $(\mathbf{n}=20){ }^{\mathrm{z}}$

\begin{tabular}{|c|c|c|}
\hline Cultivar & Day 6 & Day 50 \\
\hline \multicolumn{3}{|c|}{$2003-2004$} \\
\hline LB8-9 & $7.3 \mathrm{a}^{\mathrm{y}}$ & $6.6 \mathrm{a}$ \\
\hline Sunburst & $7.3 \mathrm{a}$ & $3 \mathrm{~b}$ \\
\hline Minneola & $7.3 \mathrm{a}$ & $6.5 \mathrm{a}$ \\
\hline \multicolumn{3}{|c|}{ 2004-2005 } \\
\hline LB8-9 & $\mathrm{ND}^{\mathrm{x}}$ & $5.9 \mathrm{~b}$ \\
\hline Sunburst & ND & $5.4 \mathrm{~b}$ \\
\hline Minneola & ND & $4.5 \mathrm{a}$ \\
\hline \multicolumn{3}{|c|}{$\begin{array}{l}{ }^{2} \text { The panelists were acknowledged to be trained } \\
\text { because they routinely taste juice products at the } \\
\text { University of Florida, Citrus Research and Education } \\
\text { Center, Lake Alfred. Three juice samples of } \approx 30 \mathrm{~mL} \\
\text { ( } 1.0 \mathrm{floz} \text { ) were prepared for each panelist with a cup of } \\
\text { water to be used between the juice sample tastes. A } \\
\text { total of } 40 \text { fruit stored at } 40{ }^{\circ} \mathrm{F}\left(4.4{ }^{\circ} \mathrm{C} \text { ) and } 92 \% \text { to }\right. \\
96 \% \text { relative humidity were juiced with a Handy Juicer } \\
\text { (Black and Decker) on the morning of the taste day. } \\
\text { The taste panel was conducted in the afternoon of the } \\
\text { same day. } \\
\text { y Different letters in same column mean significantly } \\
\text { different according to Duncan's multiple range test at } \\
P \leq 0.05 \text {. } \\
{ }^{x} \mathrm{ND}=\text { no data (no test was conducted on day } 6 \text { ). }\end{array}$} \\
\hline
\end{tabular}

Hortechnology $\cdot$ January-March 2007 17(1) 
not shown). Overall, LB8-9 did not show any postharvest problems. It performs rather better than 'Minneola' and 'Sunburst' from all postharvest and internal quality standpoints. In general, LB8-9 is suitable for the fresh fruit market.

\section{Literature cited}

Davies, F. and L.G. Albrigo. 1994. Fruit quality, harvesting, and postharvest technology, p. 202-215. In: F. Davies and L.G. Albrigo (eds.). Citrus. CAB Intl., Wallingford, U.K.

Dou, H. 2004. Effect of coating application on chilling injury of grapefruit cultivars. HortScience 39:558-561.

Dou, H. and M.A. Ismail. 2000. Effect of pre-cooling and storage temperature on postharvest pitting incidence of citrus, p. 131-142. In: W.J. Florkowski, S.E. Prussia, and R.L. Shewfelt (eds.). An integrated view of fruit and vegetable quality. Technomic Publ., Basel, Switzerland.
Echeverria, E. and J. Valich. 1989. Enzymes of sugar and acid metabolism in stored 'Valencia' oranges. J. Amer. Soc. Hort. Sci. 1 14:445-449.

Echeverria, E. and M.A. Ismail. 1990. Sugars unrelated to Brix changes in stored citrus fruits. HortScience 25:710 (abstr.).

Hagenmaier, R.D. and P.E. Shaw. 1992. Gas permeability of fruit coating waxes. J. Amer. Soc. Hort. Sci. 117:105-109.

Lee, H.S. 2000. Objective measurement of red grapefruit juice color. J. Agr. Food Chem. 48:1507-1511.

Lee, H.S. and G.A. Coates. 1987. Liquid chromatographic determination of vitamin $\mathrm{C}$ in commercial Florida citrus juices. J. Micronutr. Anal. 3:199-201.

McGuire, R.G. 1992. Reporting of objective color measurements. HortScience 27:1254-1255.

Meilgaard, M.C., G.V. Civille, and B.T. Carr. 1999. Sensory evaluation techniques, 3rd ed. CRC Press, Boca Raton, Fla.
Nagy, S. and J.M. Smoot. 1977. Temperature and storage effects on percent retention and percent U.S. recommended dietary allowance of vitamin $\mathrm{C}$ in canned single-strength orange juice. J. Agr. Food Chem. 25(1):135-138.

Petracek, P.D., L. Montalvo, H. Dou, and C. Davis. 1998. Postharvest pitting of 'Fallglo' tangerine. J. Amer. Soc. Hort. Sci. 123:130-135.

Purvis, A. 1983. Moisture loss and juice quality from waxed and individually scaled-packaged citrus fruits. Proc. Fla. State Hort. Soc. 96:327-329.

Saunt, J. 2000. The mandarin, p. 43-87. In: J. Saunt (ed.). Citrus varieties of the world. Sinclair Intl., Norwich, U.K.

Sparks, M.W. and M.A. Ismail. 2000. Use of health and nutritional information in marketing Florida citrus products. Proc. Intl. Soc. Citricult. 2:1068-1069.

Tucker, D.P.H., E.W. Stover, S.J. Rogers, and M.R. Ziegler. 2006. A comprehensive guide to Florida citrus: Integrated citrus management. Univ. Fla. Press, Gainesville. 